\title{
Catatan dari Managing Editor: Pengantar Vol. 19 (1) tentang kerja sama, dukungan sosial, dan altruisme
}

\author{
Joevarian Hudiyana \\ Fakultas Psikologi, Universitas Indonesia, Depok, Jawa Barat
}

\author{
"All the memories of your faces \\ Seem like days of yore \\ And if the walls are closing in \\ We'll find a window deep within" \\ (Lin \& Sun, 2020)
}

Lirik lagu di atas berasal dari lagu Stay With You, yang dinyanyikan J. J. Lin dan Stefanie Sun. Lagu ini menggambarkan situasi pandemi dimana kita semua menjaga jarak sosial dengan temboktembok yang memisahkan kita semua. Secara khusus, lagu ini dipersembahkan untuk tenaga kesehatan yang setiap hari berjuang di garda terdepan untuk melawan wabah COVID-19. Hampir satu tahun telah berlalu sejak kasus pertama virus corona diumumkan di Indonesia. Dalam waktu hampir satu tahun itu pula kita menyaksikan berbagai dinamika sosial yang terjadi sebagai konsekuensi dari wabah yang melanda seluruh dunia itu.

Wabah ini telah menunjukkan aspekaspek terburuk manusia seperti diskriminasi terhadap pasien COVID-19 (Devakumar, Shannon, Bhopal, \& Abubakar, 2020), skeptisisme terhadap sains (Brzezinski, Kecht, Van Dijcke, \& Wright, 2020; Latkin, Dayton, Moran, Strickland, \& Collins, 2021), teori konspirasi (Imhoff \& Lamberty, 2020; Uscinski, dkk., 2020), ketidakpatuhan dalam menjalankan pembatasan sosial (Van Lissa dkk., 2020), dan ditambah lagi dengan respon buruk oleh para pemimpin negara di berbagai belahan dunia (Norrlöf, 2020).

Meski demikian, situasi krisis ini juga memunculkan sisi terbaik yang dimiliki oleh manusia. Lagu yang dipersembahkan untuk tenaga kesehatan di awal tulisan ini menunjukkan betapa heroiknya mereka yang rela berkorban demi keselamatan kitas semua. Di samping itu, tim peneliti psikologi sosial dari seluruh dunia juga bekerja sama untuk menyelidiki pola perilaku dari reaksi COVID-19 (lihat psycorona.org). Tim PsyCorona ini terdiri atas ratusan peneliti dari berbagai negara. Di Indonesia, PsyCorona diwakili oleh Dr. Mirra Noor Milla, Prof. Dr. Hamdi Muluk, dan saya sendiri (Universitas Indonesia) serta dr. Cokorda Bagus Jaya Lesmana, Sp.KJ (Universitas Udayana). Kerja sama ini melahirkan berbagai artikel yang sudah terbit dan sedang dalam proses penilaian di jurnal.
Dari situ, bisa kita lihat bahwa krisis seperti pandemi COVID-19 ini juga memicu altruisme, perilaku menolong, dan perilaku bekerja sama. Situasi krisis memang telah didemonstrasikan secara empiris bisa memicu kerja sama dan perilaku bahu-membahu memberikan dukungan sosial (Cheng, Lam, \& Leung, 2020; Hu \& Zhou, 2020; Rodriguez, Trainor, \& Quarantelli, 2006). Namun, bagaimanakah proses dan dinamika yang timbul agar bisa memunculkan altruisme? Riset terkait altruisme masih dibutuhkan dalam berbagai konteks, tak terkecuali di konteks Indonesia.

Dalam Volume 19 edisi pertama di tahun 2021 ini, Jurnal Psikologi Sosial mempublikasikan delapan naskah empiris dengan tema kerja sama, dukungan sosial, dan altruisme. Naskah pertama ditulis oleh Nugroho, Sajuthi, Mansjoer, Iskandar, dan Darusman yang membahas bagaimana kerja sama bisa muncul pada spesies Macaca fascicularis atau monyet ekor panjang. Riset ini berkontribusi untuk memahami dalam konteks apa perilaku kooperatif dan kerja sama muncul pada primata. Pengetahuan ini membantu kita untuk memahami hasil perkembangan evolusi manusia dan primata-primata lainnya.

Naskah kedua ditulis oleh Permatasari, Agustiani, dan Bachtiar. Mereka menunjukkan secara empiris bahwa anak prasekolah masih kesulitan untuk memahami emosi yang diekspresikan orang lain. Sehingga, empati dan altruism lebih sulit terjadi. Ini berbeda dengan asumsi dari teori sebelumnya tentang tahapan perkembangan anak.

Sementara itu, naskah ketiga ditulis oleh Rhodes, Andiyasari, dan Riantoputra. Mereka menemukan bahwa peran pimpinan atau manajer penting untuk merangkul karyawan yang tidak berani bersuara karena nilai power distance. Pimpinan yang lebih terbuka dapat membantu karyawan-karyawan ini untuk lebih berani berpendapat atau menunjukkan voice behavior.

Naskah keempat ditulis oleh Rozi dan Prasasti. Mereka menemukan bahwa resiliensi adalah produk dari kesabaran sebagai nilai kebajikan. Nilai kesabaran sebagai salah satu nilai kebajikan ditransimisikan secara intens dalam kebudayaan Indonesia dan dianggap sebagai nilai yang luhur. Nilai ini merupakan mekanisme 
adaptasi yang unik, dan menjadi simbol dari perilaku prososial di masyarakat (Lestari, 2016). Sementara itu naskah kelima ditulis oleh Firmansyah, Faturochman, dan Minza. Mereka menemukan bahwa rasa saling percaya antar teman bisa diprediksi oleh adanya dukungan sosial dan adanya resiprositas. Namun menariknya, kedekatan interpersonal bukan prediktor yang signifikan jika dibandingkan dengan dua prediktor lain. Ini berimplikasi pada pertanyaan tentang seberapa penting kelekatan interpersonal dalam hubungan pertemanan di Indonesia. Apakah penting? Ataukah lebih penting aspek dukungan sosial dan hubungan timbal balik yang ditunjukkan seorang teman?

Naskah keenam oleh Pratiwi dan Afiatin menunjukkan bahwa peranan orangtua sangat penting dalam memprediksi kecanduan internet pada remaja. Ini karena mediasi oleh orangtua bisa menciptakan rasa keberhargaan diri pada remaja. Sementara itu naskah ketujuh merupakan riset yang ditulis oleh Luliyarti, Yahya, dan Ridha menggunakan teknik door in the face dan foot in the door untuk mencoba membuktikan intervensi seperti apa yang bisa meningkatkan perilaku prososial. Terakhir, naskah oleh Dienillah dan Chotidjah menemukan bahwa adanya dukungan sosial sangat penting untuk memoderasi apakah penerimaan diri mampu menciptakan rasa syukur pada penderita lupus.

Kami selaku tim editor JPS berharap naskah-naskah yang dipublikasikan pada edisi ini bisa berdampak bagi perkembangan ilmu di Indonesia, khususnya terkait topik perilaku prososial dan perilaku kerja sama.

\section{Daftar Pustaka}

Brzezinski, A., Kecht, V., Van Dijcke, D., \& Wright, A. L. (2020). Belief in science influences physical distancing in response to covid-19 lockdown policies. University of Chicago, Becker Friedman Institute for Economics Working Paper, (2020-56). http://doi.org/10.2139/ssrn.3587990

Cheng, K. K., Lam, T. H., \& Leung, C. C. (2020). Wearing face masks in the community during the COVID-19 pandemic: altruism and solidarity. The

Lancet. https://doi.org/10.1016/S01406736(20)30918-1

Devakumar, D., Shannon, G., Bhopal, S. S., \& Abubakar, I. (2020). Racism and discrimination in COVID-19 responses. The Lancet. $\quad$ https://doi.org/10.1016/S01406736(20)30792-3

$\mathrm{Hu}$, J., He, W., \& Zhou, K. (2020). The mind, the heart, and the leader in times of crisis: How and when COVID-19-triggered mortality salience relates to state anxiety, job engagement, and prosocial behavior. Journal of Applied Psychology, 105(11), 1218. https://doi.org/10.1037/apl0000620

Imhoff, R., \& Lamberty, P. (2020). A bioweapon or a hoax? The link between distinct conspiracy beliefs about the Coronavirus disease (COVID-19) outbreak and pandemic behavior. Social Psychological and Personality Science,11(8), 1110-1118. https://doi.org/10.1177/19485506209346 92

Latkin, C. A., Dayton, L., Moran, M., Strickland, J. C., \& Collins, K. (2021). Behavioral and psychosocial factors associated with COVID19 skepticism in the United States. Current Psychology,

1-9. https://doi.org/10.1007/s12144-02001211-3

Lestari, R. (2016). Transmisi nilai prososial pada remaja Jawa. Indigenous: Jurnal Ilmiah Psikologi, 1(2). https://doi.org/10.23917/indigenous.v1i1. 3043

Lin, J. J., \& Sun, S. (2020). Stay with you [Recorded by Lin, J. J., \& Tan, M.]. On Youtube (MP4 video). The JFJ Lab and Make Music Studio.

Norrlöf, C. (2020). Is COVID-19 the end of US hegemony? Public bads, leadership failures and monetary hegemony. International Affairs, 96(5), 1281-1303. https://doi.org/10.1093/ia/iiaa134

Rodriguez, H., Trainor, J., \& Quarantelli, E. L. (2006). Rising to the challenges of a catastrophe: The emergent and prosocial behavior following Hurricane Katrina. The annals of the American academy of political and social science, 604(1), 82-101. https://doi.org/10.1177/00027162052846 77

Uscinski, J. E., Enders, A. M., Klofstad, C., Seelig, M., Funchion, J., Everett, C., ... \& Murthi, M. (2020). Why do people believe COVID-19 conspiracy theories?.Harvard Kennedy School Misinformation Review, 1(3). https://doi.org/10.37016/mr-2020-015

Van Lissa, C. J., Stroebe, W., Leander, P., Agostini, M., Gutzkow, B., Kreienkamp, J., ... \& PsyCorona Collaboration. (2020). Early Indicators of COVID-19 Infection Prevention Behaviors: Machine Learning Identifies Personal and Country-Level Factors. Retrieved from: https://psyarxiv.com/whjsb/

Wilson, S. (2020). Pandemic leadership: lessons from New Zealand's approach to COVID19. Leadership, 16(3), 279-293. https://doi.org/10.1177/17427150209291 51 